\title{
TU/e EN⿴HOUN

\section{How do policies help to increase the uptake of carbon reduction measures in the EU residential sector? Evidence from recent studies}

\section{Citation for published version (APA):}

Laes, E., Mayeres, I., Renders, N., Valkering, P., \& Verbeke, S. (2018). How do policies help to increase the uptake of carbon reduction measures in the EU residential sector? Evidence from recent studies. Renewable and Sustainable Energy Reviews, 94, 234-250. https://doi.org/10.1016/j.rser.2018.05.046

\section{Document license:}

TAVERNE

DOI:

10.1016/j.rser.2018.05.046

Document status and date:

Published: 01/10/2018

\section{Document Version:}

Publisher's PDF, also known as Version of Record (includes final page, issue and volume numbers)

\section{Please check the document version of this publication:}

- A submitted manuscript is the version of the article upon submission and before peer-review. There can be important differences between the submitted version and the official published version of record. People interested in the research are advised to contact the author for the final version of the publication, or visit the $\mathrm{DOI}$ to the publisher's website.

- The final author version and the galley proof are versions of the publication after peer review.

- The final published version features the final layout of the paper including the volume, issue and page numbers.

Link to publication

\footnotetext{
General rights

- You may freely distribute the URL identifying the publication in the public portal. follow below link for the End User Agreement:

www.tue.nl/taverne

\section{Take down policy}

If you believe that this document breaches copyright please contact us at:

openaccess@tue.nl

providing details and we will investigate your claim.
}

Copyright and moral rights for the publications made accessible in the public portal are retained by the authors and/or other copyright owners and it is a condition of accessing publications that users recognise and abide by the legal requirements associated with these rights.

- Users may download and print one copy of any publication from the public portal for the purpose of private study or research.

- You may not further distribute the material or use it for any profit-making activity or commercial gain

If the publication is distributed under the terms of Article 25fa of the Dutch Copyright Act, indicated by the "Taverne" license above, please 


\title{
How do policies help to increase the uptake of carbon reduction measures in the EU residential sector? Evidence from recent studies
}

\author{
Erik Laes $^{\mathrm{a}, *}$, Inge Mayeres ${ }^{\mathrm{b}}$, Nele Renders ${ }^{\mathrm{a}}$, Pieter Valkering ${ }^{\mathrm{a}}$, Stijn Verbeke ${ }^{\mathrm{c}}$ \\ a VITO, EnergyVille, Thor Park, 3600 Genk, Belgium \\ b Transport and Mobility Leuven, KU Leuven, Belgium \\ ${ }^{\mathrm{c}}$ VITO, EnergyVille, University of Antwerp, Belgium
}

\section{A R T I C L E I N F O}

\section{Keywords:}

Energy efficiency

Residential sector

Panel data studies

Applied behavioural research

Situated accounts

\begin{abstract}
A B S T R A C T
The residential sector is one of the EU's priority sectors where carbon mitigation needs to be realised. In this paper, we carry out a review of the effectiveness of individual policies or policy packages in terms of the uptake of these carbon mitigation measures and/or energy savings realised as a result. The focus lies on the existing residential building stock. The literature reviewed in this paper covers panel data studies, applied behavioural research, and situated approaches. Most of the reviewed quantitative studies find that financial incentives and subsidies have a positive impact on the probability of energy efficiency improvements being undertaken. However, when evaluating the energy efficiency improvements or $\mathrm{CO}_{2}$ reductions induced by the incentives and therefore their effectiveness, the presence of free riding turns out to be a problem. Energy and $\mathrm{CO}_{2}$ taxation should play a larger role in encouraging people to save energy and reduce $\mathrm{CO}_{2}$ emissions, since the reviewed studies indicate that people are responsive to savings in energy costs and expected price increases in the future. The evidence on the relative impact of regulation vs. financial incentives is inconclusive. For information policies the quantitative evidence is still limited. The reviewed panel data studies find no or a negative impact. This finding however does not necessarily imply that information policies are useless, as panel data do not allow for a detailed analysis of different types of informational approaches. Situated accounts provide further necessary qualitative findings on best practices for energy savings by households.
\end{abstract}

\section{Introduction}

In the vision put forward in the 7th Environmental Action Plan for the EU [1], in 2050, "we live well within the planet's ecological limits. [...] our low-carbon growth has long been decoupled from resource use, setting the pace for a safe and sustainable global society." By 2050 greenhouse gas (GHG) and air pollutant emissions should therefore be far below current levels. The target for GHG emissions is set at a reduction of $80-95 \%$ compared to 1990 levels [2].

The residential sector is one of the priority sectors where carbon mitigation needs to be realised. Carbon mitigation measures in the residential sector fall into the following categories: improving the energy efficiency of newly built residential buildings, renovating the building envelope of existing buildings (e.g. replacing window with high-efficiency glazing, installing cavity or roof insulation, etc.), improving heating, ventilation, cooling and domestic hot water installations (upgrading to more efficient installations or adopting renewable heating and/or cooling solutions), incorporating on-site renewable energy production (e.g. roof photovoltaic installations), installing more efficient household and lighting appliances, and/or changing behaviour in a more frugal direction.

In this paper, we carry out a review of the effectiveness of individual policies or policy packages in terms of the uptake of these carbon mitigation measures and/or the energy savings realised as a result. The focus lies on the existing residential building stock. Policies are intended to strengthen the drivers for the uptake of carbon mitigation measures, offer solutions for the barriers and mitigate the negative influences. A distinction can be made between different policy classes:

- economic incentives: taxes, tax credits, grants or subsidies, etc.;

- regulatory instruments: mandatory norms for the energy performance of buildings, energy efficiency regulations for heating and hot water systems, etc.;

- institutional frameworks: for example, the institutional framework describing the rights and obligations of landlords and tenants;

- information measures: including energy audits and assessments,

\footnotetext{
Abbreviations: EU, European Union; GHG, Greenhouse gas

* Corresponding author.

E-mail address: Erik.Laes@vito.be (E. Laes).
} 
energy efficiency labels, marketing and information campaigns, etc.

The effectiveness of policies or policy packages will be different for different groups of households and home owners, as for each group quite different drivers and barriers may be at play. For the residential sector, one typically distinguishes between owner-occupied single-family homes, owner-occupied multi-family homes, and rental dwellings [3]. Owner-occupied single family homes are generally more likely to take up carbon mitigation measures as they are more involved in the choice and design of such measures and have fewer organisational barriers to consider (e.g. split incentives, ${ }^{1}$ collective decision-making and financing). Given the prevalence of owner-occupied dwellings (according to Eurostat [4], in 2015 about $70 \%$ of dwellings in the EU were owner occupied), the paper focuses mainly on decision-making in this context.

Our review paper mainly covers recent publications (both grey and peer-reviewed scientific literature) published since 2010 with the most recent studies considered dating from mid-2016, in the English language. The reader should note that while many relevant studies fall in this language category, the review is necessarily incomplete as publications in other languages were not considered. In the initial searches we used various search words such as the determinants of energy efficiency, renovations, heating systems, etc. and consulted journal databases (e.g. Science Direct) as well as more general search engines such as Google and Google Scholar. This was followed by both forward and backward snowballing. Afterwards, a selection of reports and papers was made, keeping in mind the general purposes of our analysis as well as our interest in quantitative evidence, reducing the long-list of studies from about 140 to those considered here.

Research on household decision-making processes leading to the adoption of carbon mitigation measures is interdisciplinary, drawing on insights from economics, psychology and sociology [5]. For the purposes of the paper, the literature reviewed can be classified into one of the following categories: panel data studies, applied behavioural research, ${ }^{2}$ and situated approaches (cf. Table 1). Each of these disciplines starts from a different perspective on household decision-making.

First of all, we consider the evidence that can be derived from panel data studies covering different countries for a period of time (Section 3). This approach is aggregate or macro-level in nature. It offers a broad overview of the extent to which residential energy use has been affected in the past by policies and other determinants, without considering exactly the causal chain affecting energy use or how households take their decisions. This is followed by the more micro-level approach of applied behavioural research (Section 4) that considers the way in which policies or other determinants may influence the households' decision-making process, based on revealed or stated preference data. In this case more specific energy efficiency measures, such as home insulation or the replacement of a heating system, are studied in addition to general indicators of energy efficiency. As summarised in Wilson et al. [6] for renovation decisions, applied behavioural research considers various decision influences: personality traits (e.g. attitudes and beliefs), contextual influences (e.g. socio-demographic characteristics of the household, property characteristics such as the age of the building, the number of rooms, etc.) and the attributes of energy renovations (e.g. the energy savings to be realised and the associated

\footnotetext{
${ }^{1}$ Such split incentives may arise, for example, when the owner and occupier of a house are not the same person. In that case the incentives for energy savings are not aligned between the two of them. When the landlords invest in energy efficiency, they will not personally benefit from those investments if the energy bill is paid by the tenants and the contract does not allow for an increase in the rent after the investment. This will lead to underinvestment in energy efficiency and is referred to in the literature as the landlord/ tenant dilemma.

${ }^{2}$ In the terminology of Wilson et al. (2015, p. 12), applied behavioural research refers to "research concerned foremost with empirical findings on behaviour and decision-making, particularly in a domestic context, and with how these findings can be applied in policy or intervention design.".
}

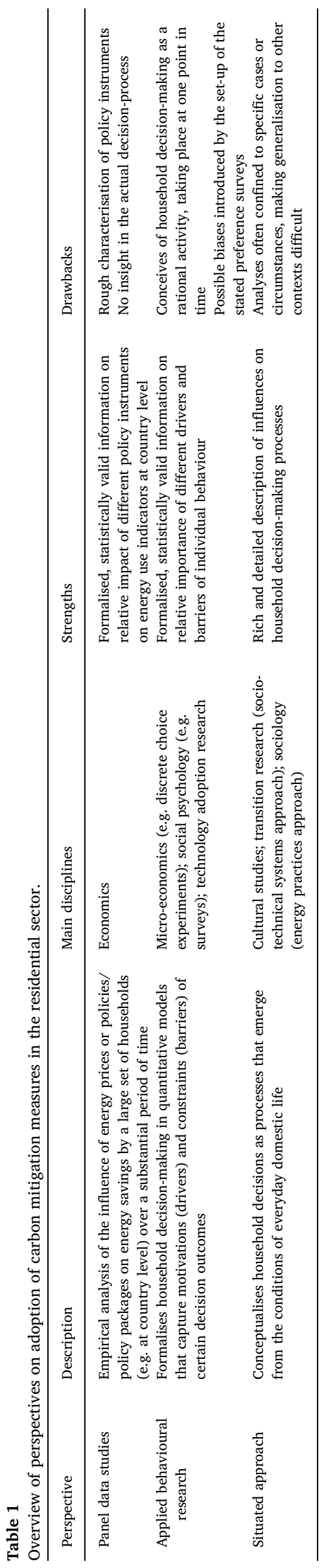




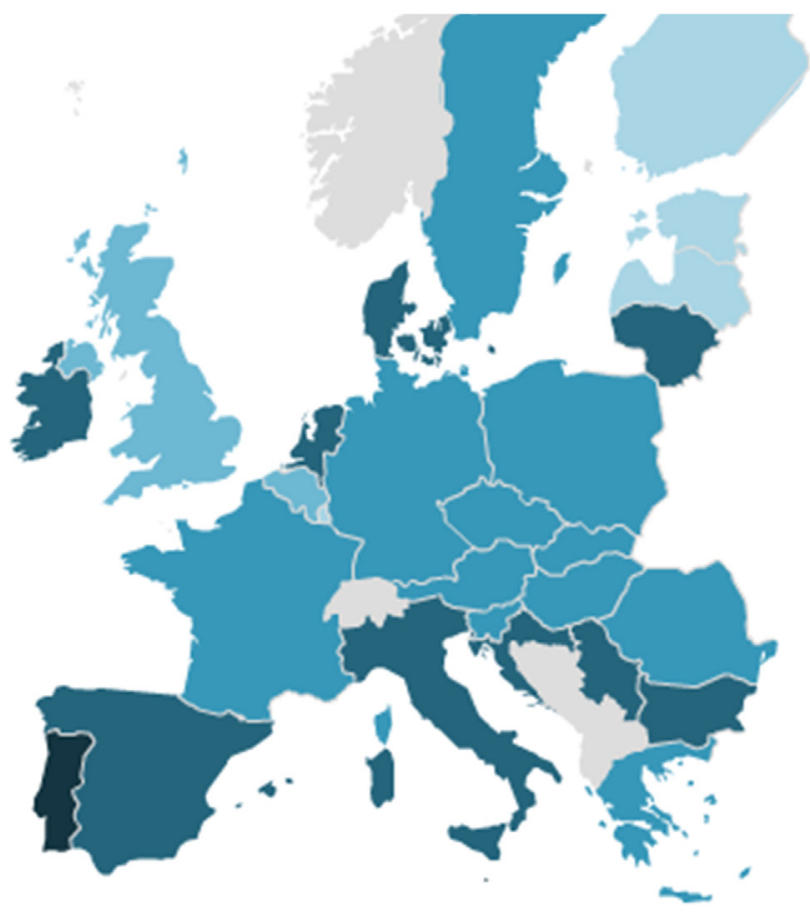

\begin{tabular}{|l|}
\hline Unit : $\mathrm{kWh} / \mathrm{m}^{2}$ \\
$<100$ \\
100 to 200 \\
200 to 250 \\
250 to 300 \\
$>300$ \\
No data
\end{tabular}

Fig. 1. Final energy consumption per $\mathrm{m}^{2}$ in residential sector (at normal climate) in $2008 .^{4}$ Source: Entranze, http://www.entranze.enerdata.eu/.

payback periods). These studies also take into account some commonly identified cross-cutting drivers (e.g. the desire to realise cost-savings whilst enhancing thermal comfort and indoor air quality) and barriers (e.g. the lack of available capital, the lack of upfront information, the uncertainty about energy savings, and the cognitive burden of making complex and irreversible decisions).

A general critique of applied behavioural studies is that their set-up often focuses exclusively on the financial aspects of renovations at the expense of other relevant factors influencing the decision whether or not to adopt a carbon mitigation measure, which makes it more likely that these aspects will be found to have an impact [7]. It is also pointed out that renovation is a process rather than something which happens at one point in time and that decision-making by households cannot be reduced to decision-making by a single rational individual. These aspects are studied by so-called "situated accounts" informed by sociology. Situated accounts provide a rich description of household decision-making as a process, accounting for the symbolic meaning of homes, renovations as activities embedded in routines of daily life, and relationships (and tensions) within households [6]. In Section 5 we therefore complement the evidence from panel data studies and applied behavioural research with insights from situated accounts that suggest ways of reforming existing policies. It should be noted however that because of the qualitative nature of the research outcomes from that literature, generalisations to other contexts are more difficult to make.

While the quantitative household models mainly cover building envelope renovations and improvements in heating and hot water systems, Section 5 will also look more closely at qualitative evidence on behavioural changes.

The literature reviewed in Sections 3 to 5 analyses the success or failure of policies/policy packages in terms of their ability to increase the uptake of carbon mitigation measures in the residential sector (mediated by household decisions). From a societal point of view, additional criteria have to be considered when judging success or failure. Financial incentives in the form of subsidies or (tax) rebates are frequently used to encourage people to adopt carbon mitigation measures. However, the use of those policy instruments poses specific challenges in terms of additionality (i.e. proving that the households profiting from the incentives would not have undertaken action in the absence of the incentive) and cost-effectiveness (i.e. proving that the societal cost of the policy instrument - expressed in euro/ton $\mathrm{CO}_{2}$ emission avoided - is not too high compared to the social costs of other measures). Relevant literature findings on those issues are discussed in Section 6. Finally, Section 7 concludes and discusses the relevance of the findings for EU policy making.

Before looking into the policies, Section 2 gives a short overview of the current situation in the EU.

\section{Current situation in EU}

\subsection{Building stock}

In 2013, buildings accounted for $40 \%$ of final energy consumption in the EU in total. Residential buildings accounted for a share of $27 \%$ of final energy consumption. Average household energy consumption was $1.4 \mathrm{t}$ of oil equivalent (toe) per dwelling (or $184 \mathrm{kWh} / \mathrm{m}^{2}$ ) in 2013 , with large differences between EU countries, ${ }^{3}$ as illustrated in Fig. 1 (for 2008). Thanks to the better performance of new buildings and appliances and the renovation of existing dwellings, EU energy consumption for residential space heating (measured per $\mathrm{m}^{2}$ ) has improved by on average $2.3 \%$ per year since 2000 . However, with the financial economic crisis the construction of new dwellings has slowed down since 2009 , leading to a slower penetration of new dwellings built according to demanding energy performance standards [8].

The energy performance of buildings depends on many factors, including the characteristics of the installed heating system and building envelope, climatic conditions, behaviour (e.g. the choice of the indoor temperature) and socio-economic conditions (e.g. fuel poverty) [9]. The

\footnotetext{
${ }^{3}$ See ENER 037 indicator of the EEA (Progress on Energy efficiency in Europe) http:// www.eea.europa.eu/data-and-maps/indicators/progress-on-energy-efficiency-in-europe2/assessment-1.

${ }^{4}$ In order to produce indicators of energy consumption independently of year-to-year variations in winter severity, actual consumption for space heating is normalised to a normal winter (www.entranze.enerdata.eu).
} 
largest energy saving potential can be realised in older buildings. Over $40 \%$ of residential buildings in the EU were constructed before the 1960 s, in a period with very limited building regulations with regard to energy performance. It should also be taken into account that in some cases buildings dating from the 1960s perform worse than those from earlier periods. According to the Buildings Performance Institute Europe (BPIE), deep renovation of EU buildings could cut $36 \%$ of their energy consumption by 2030, thereby reducing EU energy import dependency, creating growth, innovation and employment, reducing fuel poverty and resulting in more comfortable and healthier buildings. ${ }^{5}$

\subsection{Current EU policies and regulations on building performance}

EU legislation is a major driver in policies and measures implemented in the residential and service sector. The EU's main legislative texts covering the energy efficiency of buildings are the 2010 Energy Performance of Buildings Directive and the 2012 Energy Efficiency Directive.

Under the Energy Performance of Buildings Directive (2010/31/EU) energy performance certificates have to be included in all advertisements for the sale or rental of buildings. All new buildings constructed after 31 December 2020 must adhere to nearly-zero energy building standards (public buildings by 31 December 2018). EU Member States must set up inspection schemes for heating and air conditioning systems. They must determine minimum energy performance requirements for new buildings, for the major renovation of buildings and for the replacement or retrofit of building elements. They also have to draw up lists of national financial measures to increase the energy efficiency of buildings.

The Energy Performance of Buildings Directive has indeed resulted in strict regulations for new buildings in all EU Member States (nearlyzero energy buildings). In spite of the success of the Directive in the domain of new houses, the impact on existing houses and appliances is more limited.

Under the Energy Efficiency Directive (2012/27/EU), each year EU countries must make energy efficient renovations to at least $3 \%$ of buildings owned and occupied by central government; EU governments should only purchase buildings which are highly energy efficient; and EU countries must draw up long-term national building renovation strategies which can be included in their National Energy Efficiency Action Plans.

The EU Member States are required to transpose the EU legislation into national policies. As will be discussed below, there is a great heterogeneity in the implementation of policy packages between the different Member States, both in terms of the absolute number of policies adopted and in terms of policy type. In general, one can conclude that there is a predominance of financial, fiscal and regulatory measures [8].

\section{Panel data evidence at country level}

A number of panel data studies at country level have tried to determine ex-post the impact of policies or policy packages on energy use in the residential sector. Examples of such studies for the EU are Bigano et al. [10], Filippini et al. [11], Ó Broin et al. [12,13] and Bertoldi \& Mosconi [14]. While EU policies play the role of catalysts and harmonising devices, at national level there is still heterogeneity in policies, as illustrated in Fig. 2 for four EU countries. Among these countries, Germany relies strongly on regulatory and financial measures, Finland has a strong focus on informational/motivational measures, Romania believes strongly in regulatory measures and the Netherlands mainly in financial measures. Explaining these differences lies outside the scope of this paper. A possible explanation may be that cultural differences, societal habits or differences in the economic context lead to a different preference for the various types of measures. Our paper can however give insights into how energy efficiency could be improved in the different countries by resorting to types of measures that have not yet been introduced in the past.

The panel data studies exploit the observed heterogeneity in policies in order to investigate how policies and energy prices - including energy taxes - have influenced energy efficiency, together with other determining factors such as household income, population, heating degree days, etc. Table 2 (in the annex) summarizes the main characteristics and results of the studies, focusing on residential energy use.

All else being equal, higher energy prices are found to lead to lower energy demand, higher energy efficiency or lower carbon intensity for the residential sector. However, the elasticities imply an inelastic demand, meaning that an increase in the energy price leads to a less than proportional fall in energy demand or carbon intensity, or a much less than proportional increase in energy efficiency. As can be expected, the studies making a distinction between short- and long-term price elasticities find that in the long term the price sensitivity is higher, reflecting that people have more options to adapt in the longer term. Nevertheless, the long-run elasticities also point to an inelastic demand.

In contrast to the energy prices, the policy information that is taken into account to assess the impact of policies and policy packages in the panel data studies is descriptive, following the categories in the MURE database. $^{6}$ This means that only a rough indication of the effectiveness of policies and policy packages can be given. Moreover, since no data on policies related to competition or market liberalisation are available, the impact of those policies has not been analysed while it could still be relevant. Not all studies consider that the impact of a policy may vary over time. Among the studies reviewed here, only Ó Broin et al. [12] and Bertoldi \& Mosconi [14] allow for a delay in the impact of policies. The studies included in this review each characterise policies in a different way:

- Bigano et al. [10] include a dummy for different policy types. They find that regulation has a positive impact on energy efficiency and carbon intensity of households. However, different types of regulation play a role in two different cases: energy intensity is affected mainly by mandatory standards for buildings and the regulation of heating and hot water systems, while carbon intensity is affected through "other" building regulations. Cross-cutting measures with sector-specific characteristics and financial measures are also found to have positive impact, as well as general energy efficiency and renewable energy programs (in the case of energy efficiency) and $R$ \&D policies (in the case of carbon intensity).

- In Filippini et al. [11] the dummy variables reflect not only the presence but also the number of measures. In the model they choose as the most appropriate (the BC95M model), financial measures have the highest impact on estimated energy efficiency. The results are similar for the dummies that present up to 2 or more financial measures. Information measures, which contain labelling, surprisingly lead to a lower energy efficiency. The authors point to the rebound effect, associated with a more intensive use of energy-saving equipment, as a possible explanation. Among the regulatory measures, the performance standards of buildings, heating systems and appliances have a positive effect on energy efficiency, but less so than financial measures. The authors refer to the longer penetration time of the regulations as they apply to new buildings and appliances.

- In the sectoral estimations of Bertoldi \& Mosconi [14] the number of policy measures is used as one of the explanatory variables for residential energy demand. They include 576 measures in total that apply in the EU-28 countries and Norway, of which 35\% can be termed fiscal/financial/tariffs. According to their estimations, an additional measure would lead to a reduction in residential energy 


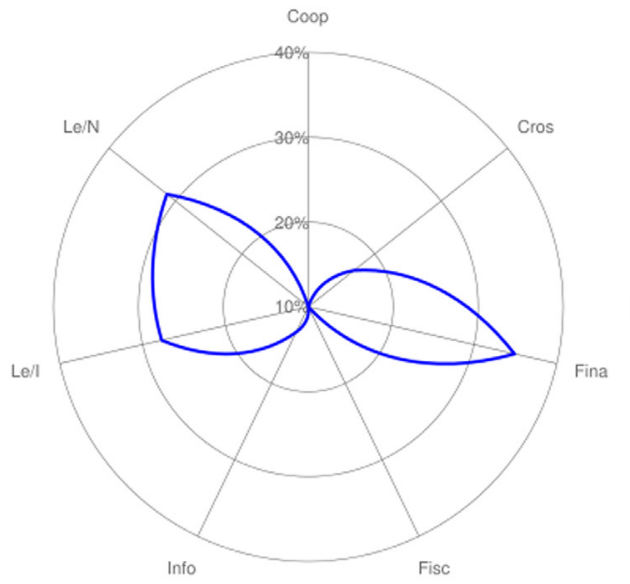

After $1994(42)$

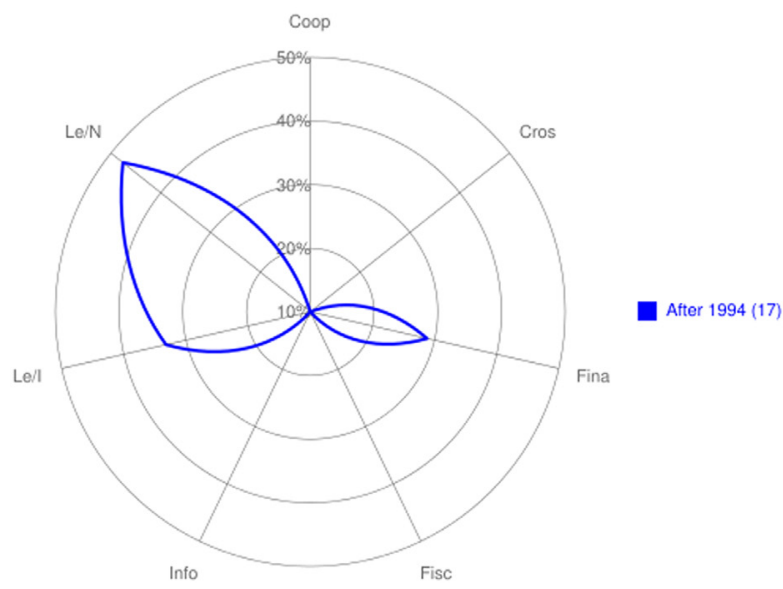

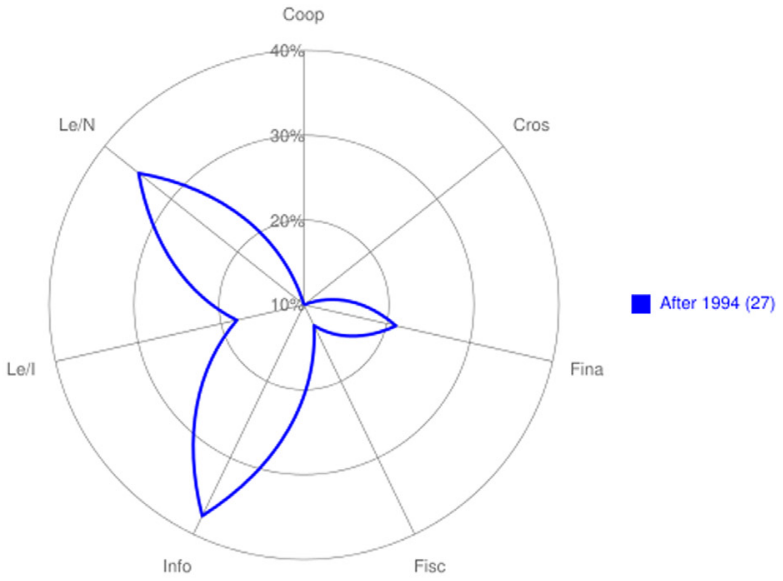

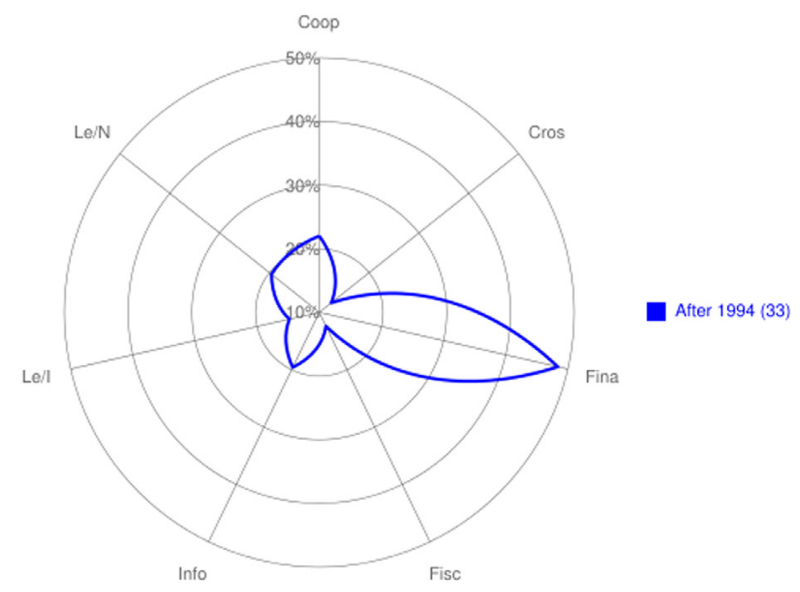

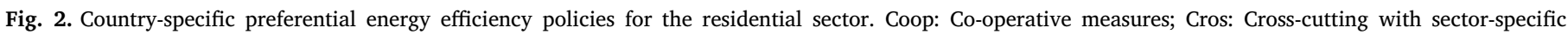
characteristics; Fina: financial; Fisc: Taxes/tariffs; Inf: Information/Education; Leg/Inf: Legislative/Informative; Leg/N: Legislative Normative.

Source: Odyssee-Mure, 2015, p. 54.

demand of $0.19 \%$ in the short run and $0.39 \%$ in the long run. However, the authors make no distinction between different policy types. They calculate that in the absence of energy policies, residential energy consumption in the EU-28 plus Norway would have been approximately 10\% higher in 2013 .

- Finally, Ó Broin et al. [12] consider the factors determining space heating demand per square meter. To analyse the impact of policy measures, they consider three classes of policies, for which they take the sum of the policies with a grading scheme according to the estimated impact. They also consider policy lags of up to seven years, in order to analyse the dynamics of the policy effects. Regulatory policies are found to have an immediate impact from the first year of implementation onwards. One additional unit of regulation is found to reduce demand by $0.25 \%$ in the year of introduction and by $0.33 \%$ after 7 years. This class is found to have a consistent impact over the years. Financial policies only have a small impact in the year of introduction and require a number of years before having a significant impact. After 7 years, one extra unit is expected to lead to a $0.15 \%$ reduction in household energy demand. No statistically significant impact is found for information policies. Importantly, the authors also point out that because of disparities in the data, the difference in magnitudes between the instrument types may be more interesting than the magnitudes themselves.

In the case of regulatory measures, the concern is sometimes raised that they may lead to counteractive side effects. For example, Itinera
[15] points out that if the cost of new houses rises due to stricter energy efficiency regulations, the demand for existing houses increases. As a result, the prices of existing houses will rise, so households tend to have less money available to renovate the poor-performing buildings. Furthermore, the increased monetary value of existing buildings might impede buildings being demolished and rebuilt to stringent contemporary standards, and rather lead to an increased share of less performant partially renovated buildings. However, these aspects cannot be investigated by means of the panel data studies and require modelling of the housing market.

All reviewed studies also consider other explanatory factors apart from the policy measures and energy prices such as income, population, heating degree days, climate, etc. For example, Madlener et al. [16] find a short- and long-run income elasticity of respectively 0.2 and nearly 1 for residential electricity demand, and respectively 0.44 and 0.94 for residential natural gas demand. Energy demand would therefore rise less than proportionally with income in the short run, while in the long run the relationship would be (almost) proportional. It should be noted however, that the study does not explicitly consider non-pricing policies, which could also be relevant. Some studies also include a trend variable capturing factors such as autonomous technological progress, policies, fuel switching or structural effects. ${ }^{7}$ In Ó Broin et al.

\footnotetext{
${ }^{7}$ Structural effects include, for example, the preferred indoor temperature or the time spent at home.
} 
[12] the trend indicates a reduction in space heating energy demand per square meter of $1-2 \%$ per year. According to Ó Broin et al. [13], trend variables would account for a reduction of space heating demand of $0.5 \%$ for Sweden and $0.7 \%$ for the UK (also including energy demand for water heating in that study).

\section{Micro-level evidence of the choice determinants at household level}

Apart from panel data analysis at the country level, analysis at the household level also gives evidence of the impact of various determinants. In our discussion, we focus on a selection of recent studies in the field of applied behavioural research, adding to already published overviews, such as Achtnicht \& Madlener [17]. Compared to that review, the studies reviewed here differ by considering other choice sets (including e.g. also the option to do nothing, or a broader set of energy efficiency measures), other explanatory factors (such as social capital), or other countries or by using more sophisticated econometric techniques. A summary is presented in Table 3 (in the annex). Most of the selected studies focus on home owners. Charlier [18] and Longhi [19] also look at people who rent their house, an aspect that is relevant for the so-called landlord-tenant dilemma.

Various choice dimensions are analysed based on different data types. For instance, Michelsen \& Madlener [20] conduct a survey among German homeowners who have invested in a renewable heating system and who have received a grant for this. Therefore, they analyse the observed choices between different renewable heating systems conditional upon a previous decision to install one in the first place.

Four studies use stated preference surveys and consider the choices that homeowners make between hypothetical alternatives. Such a setup may lead to biases due to the hypothetical nature of the questions if the respondents are not familiar with the context presented to them in the survey (Bateman et al. [45]), a problem which is likely to arise less in the case of homeowners who have to make choices about for instance heating equipment (Alberini et al. [21]). Achtnicht \& Madlener [17] consider the more general choice between the status quo (doing nothing), choosing a modern heating system and insulating the dwelling. Alberini et al. [21] offer people the choice between the status quo and an energy efficiency investment. Apart from the economic attributes of the investment, they also consider the thermal comfort provided by it. Jäggi \& Axhausen [22] further expand the choice set by also considering options that have an influence on energy demand for transport purposes. Their aim is to explore whether households work with a budget for energy costs when making their decisions; and if so, to investigate whether households have a separate budget for energy for transport and domestic energy consumption. They point out however, that the respondents were quite unfamiliar with the decisions they had to make, so that no conclusive results could be drawn about this latter question. Alberini \& Bigano [23] analyse what kind/level of rebate would be sufficient to convince homeowners who do not already plan to replace their heating systems in the near future.

The three remaining studies in Table 3 are based on revealed choices. Cirman et al. [24] look at the renovation decisions of Slovenian households, both in family houses and multi-dwelling buildings. Their study is unique in that it pays special attention to the role of social capital. Charlier [18] analyses the determinants of past household expenditures for energy efficiency renovations based on French databases on houses and house renovations. Longhi [19] uses the UK household longitudinal survey to explore the determinants of household per capita energy expenditures and short-term changes in these expenditures.

Micro-level studies are mainly useful for gauging the potential impact of economic measures, in addition to the influence of socio-demographic characteristics and attitudes of the household, social capital indicators, and the characteristics of the dwelling, on the choice to invest in energy efficiency measures. In our discussion we therefore focus on these determinants. None of the selected studies explicitly consider regulatory or legislative measures as explanatory variables, implying that they do not allow any conclusions to be drawn as to their effectiveness. The same holds for informational measures, which are only included to a limited extent. Section 5 will therefore complement the findings with insights on these issues from situated accounts.

\subsection{Impact of the socio-demographic characteristics and attitudes of the households}

The socio-demographic characteristics of households generally affect the general and practical acceptance of carbon reduction measures. In some of the studies reviewed by Achtnicht \& Madlener [17], these factors were found to be less important or even insignificant, while in others income was cited as a factor.

One underlying factor is the perceived novelty of the concerned measures [3], which may depend on the homeowners' perception, but also on the context (e.g. the extent to which the market for these measures is developed). Typical adopters of innovative systems are younger, more educated and wealthier than average. Income level is an important characteristic as well. Low-income households are mostly concerned with the initial investment costs, middle-income households tend to consider energy cost savings as well, and the wealthiest households are relatively insensitive to costs.

These general insights are confirmed by the findings reported in Table 3. A high education level stands out as a key factor in support of the uptake of low-carbon measures. The income level and availability of financial resources is also an important factor, mostly appearing as a constraint for those less well off. The age of homeowners matters, but with varying influences. Older age may either enhance or reduce the probability of uptake, depending on specific factors on a case-by-case basis. Finally, the studies suggest that household composition (no. of household members, no. of minors in the household, gender) is a relevant factor to consider.

Looking specifically at homeowners' attitudes, one finds that environmental benefits, in particular climate change considerations associated with $\mathrm{CO}_{2}$ reduction, are an important reason for carrying out energy efficiency renovations. Another main driver is the extent to which people feel connected to their neighbourhood (i.e. knowing most of the neighbours, friendship with the neighbours, and attachment to neighbourhood) [24].

\subsection{Impact of the characteristics of the dwellings}

The characteristics of the dwellings play an important role, as was also found in previous studies. The studies reported in Table 3 suggest that the age of the building, the current level of insulation, the efficiency of the heating systems and associated running costs are key. For choosing a particular renewable heating system, there is a tendency to stick to the current type of system or at least a system with similar characteristics, with e.g. a higher probability of choosing a gas-fired condensing boiler with solar thermal support if the previous installation was gas-fired as well. Ease of use, independency from fossil fuels and achieving energy savings are also relevant factors for choosing a particular renewable heating system, although it depends on the particular system whether these are evaluated positively or negatively [20]. Finally, the building location (e.g. close to a big city or not), the size of the dwelling, and specific constraints imposed by house infrastructure (such as access to the gas network or the presence of central heating) play a role.

\subsection{Factors influencing the costs and benefits of the choices}

The factors influencing the costs and benefits of the choice options have the expected impact. Achnicht \& Madlener [17], for example, find that higher acquisition costs and a longer payback period make the choice of a modern heating system or insulation less attractive, while 
their attractiveness is increased by a larger energy cost saving potential and the expectation of an energy price increase. The findings of Alberini et al. [21], Alberini \& Bigano [23], Charlier [18] and Jäggi \& Axhausen [22] go in the same direction. Cirman et al. [24] find that higher running costs of the building, which include energy costs, increase the probability of renovation.

When considering the choice between different heating systems, conditional upon the choice to replace the heating system and for homeowners that received a grant to replace the system, Michelsen \& Madlener [20] mention however that these "homeowners do not seem to reflect on all types of costs when taking their decisions. They rather include or exclude certain costs in the decision-making process". The authors point out that this may be due to lack of awareness of all costs or to the fact that some cost components, such as maintenance costs, are small. To illustrate, the presence of the grant did have an impact, but only for two technologies, with a positive impact in one case and a negative in the other.

When financial incentives (private or public) and subsidies are taken into account explicitly, they have a positive impact on the probability of energy efficiency improvements being undertaken $[17,21]$, except in the study by Charlier [18] on energy efficient improvements by French households. In this study, energy savings are shown to have a positive impact on the energy efficiency expenditures, but no evidence was found for an impact of the French tax credit scheme according to which taxpayers can deduct part of the expenses for energy-efficient renovations.

Respondents who expect future increases in energy prices have a higher probability of energy efficiency investments being undertaken $[17,21]$. People who are uncertain about future price developments rather opt for the status quo [21]. According to Hassett \& Metcalf [25] it may be optimal for a rational household to postpone the investment in the case of uncertainty about future prices when the investment is irreversible. Alberini et al. [21] also find that people who state that climate change considerations are an important driver for energy efficient renovations give a higher weight to the energy cost savings of those renovations. Information policies may therefore play an important role in encouraging energy efficient renovations and strengthening the incentives given by the economic instruments.

\section{Situated accounts on the uptake of carbon mitigation measures in the residential sector}

Situated accounts generally start from the observation that households do not consume energy directly, but instead engage in practices or activities of everyday life that require energy. As conceptualised by practice theory $[26,27]$, in the enactment of a practice, 'materials' (e.g. technological devices), 'competences' (e.g. knowing how to operate the technical device) and 'meanings' (i.e. the symbolic significance of the practice) come together. Instead of targeting the energy consumption of households directly, or targeting households individually as rational decision makers, practice theory proposes to target their (bundles of) practices. Changing practices (and their related impact in terms of energy end-use patterns) therefore requires restructuring the existing links between the materials, competences and meanings that constitute the practice as such. In this section, we discuss insights on situated approaches aiming for the uptake of carbon mitigation measures in energy-related practices, either by stimulating behavioural change (using appliances present in the household less often or more efficiently) through energy consumption feedback or by facilitating investments in renovation.

\subsection{Stimulating energy-saving behaviour by energy consumption feedback}

Multiple empirical studies have already examined the extent to which feedback can reduce energy consumption in households. In these studies feedback is defined broadly, taking into account various feedback channels ranging from awareness campaigns to dedicated in-home displays showing energy consumption in real time. In a recent literature overview, Buchanan et al. [28] report that some studies have found no statistically significant effects at all, while others have reported energy savings ranging from $3 \%$ to $20 \%$. The authors attribute the considerable variation to (i) differences in specific feedback forms (ranging from simple marketing campaigns to the use of dedicated in-home displays), (ii) difference in the duration of trials (with a predominance of short-term trials, i.e. up to 3 months), (iii) the use of diverse study groups (ranging from self-selected volunteers to random population samples), (iv) the use of multiple feedback interventions within one study, making it difficult to pinpoint the effects of single interventions and (v) a mixed quality of the studies (more robust studies make use of a control group and correct for other intervening factors such as household demographics or the influence of the weather on energy savings).

However, despite the lack of robust statistical evidence, there are some qualitative indications regarding the most promising strategies for giving feedback to residential energy end users.

- Feedback with advice on appropriate actions: Darby [29] argues that not only technology or economic incentives should be considered as drivers of household behaviour, but also competences and daily routines. These factors determine the interface, feedback, message and support that will be most effective for influencing specific segments of consumers. Darby [29] concludes that feedback interfaces should be designed to facilitate understanding, and that households should be guided towards appropriate action through frequent and clear practical instructions, related to their practices of energy consumption (e.g. doing the laundry, washing the dishes, lighting the house, etc.). This qualitative observation is supported by some quantitative evidence. Ehrhardt-Martinez [30] finds in her study that weekly feedback plus advice on energy-saving actions generates more behavioural change and savings than continuous real time feedback through a monitor only.

- Direct versus indirect feedback findings: Darby [29] finds that direct feedback has on average a higher impact than indirect feedback. Providing direct feedback via in-home displays (i.e. real-time and historic usage feedback information) led to a permanent energy reduction of 5-15\%; end users changed their habits and invested in energy-efficiency measures. Savings from indirect feedback (i.e. information that has been processed before reaching the consumer, usually via billing) were up to $10 \%$. Darby also concludes that comparison with own historic use seems more effective than comparison with other households or objectives. This is however somewhat in contradiction with findings on social feedback reported next.

- Social feedback: Several pilots and studies show that social feedback is an effective driver for behavioural change. The eco-team approach of Staats et al. [31] achieved a reduction by $8 \%$ and British Gas' Green Streets competition achieved a reduction by $25 \%$ (albeit with a prize of $£ 50000$ as an incentive for the winning street). Another experiment by Black et al. [32] with eco-meters and social marketing (targeted strategies to ameliorate barriers or maximize benefits associated with reduced electricity or gas consumption) resulted in a reduction in consumption by $22 \%$. Ehrhardt-Martinez [30] finds that 'motivational elements', such as goal setting, competitions and social comparisons can significantly influence behaviour and generate significant additional savings. On the other hand, Ayres et al. [33] show that utility-based pilot programs with comparative energy use mailings or bill inserts produce household energy savings of only $2 \%$ on average, which might mean that specific comparison with certain reference groups causes the shift in behaviour, compared to non-specific reference groups.

Beyond these findings, there is also some qualitative evidence on the 'human factor' of end-user interaction with feedback devices. The 
'human factor' is a broad term referring to issues such as interest, motivation, comprehension, evaluation, reflection, etc. on the side of residential end users regarding energy saving in general, or the use of ICT-enabled feedback more specifically. This qualitative evidence is conveniently summarised in two recent research papers by Buchanan et al. $[28,34]$. Their most important findings are:

- ICT-enabled feedback on household energy use seems to work best only with households who have already expressed an interest in energy saving before. Even when disinterested households are offered in-home displays for free, they do not seem to use them.

- In cases where there is consumer interest in using ICT-enabled feedback, it is uncertain whether such interest will persist in the longer term. Currently, knowledge on this issue is limited, due to a scarcity of interventions examining the long-term impact of feedback.

- Making use of feedback in terms of monetary savings or financial gains only can be problematic for three reasons:

o There is a time lag between the promised financial gain through energy savings and the time when this 'reward' is actually delivered (because the majority of energy consumers pay their bills via fixed monthly payments);

o The savings obtained through feedback could be rather small in monetary terms (i.e. a couple of euros per month), which is not perceived as being very motivating;

o The emphasis on financial benefits makes the assumption that residential end users act as 'rational economic agents' making a costbenefit analysis before deciding upon the actions they are willing to undertake. Such an assumption is questionable given that residential end users do not use energy for its own sake, but rather energy use emerges as a side product of everyday actions.

- Average residential end users face severe comprehension issues when confronted with ICT-enabled feedback. Simply presenting aggregate (weekly or monthly) data on energy use is not meaningful for most people. Information has to be presented in a way that makes sense to average users, such as energy use by space (e.g. specific rooms or areas), source categories (e.g. kitchen appliances, lights) or even individual appliances.

- Personal characteristics matter in the interaction with ICT-enabled feedback devices. It may be the case that only those people with certain traits (e.g. curiosity, conscientiousness) or motives (e.g. environmental) are predisposed to instigate the necessary behavioural processes (e.g. investigation, analysis and evaluation). This finding points out the need for more understanding of the characteristics that are favourable towards using feedback for energy saving, so that targeted interventions can be designed for different user groups.

\subsection{Situated accounts of renovation projects}

Breukers et al. [35] have pointed out that understanding household decision-making as a process is a central part of a successful policy program aimed at stimulating investments in renovation measures. Influencing decisions is something that has to be worked for on multiple levels and at multiple points in time, and is not going to occur automatically by just introducing e.g. a subsidy for renovations. Households need to go through a learning experience, spanning the different stages of getting motivated (e.g. by offering some incentive or tapping into environmental values and attitudes), shaping decision intentions (e.g. deciding how and what to renovate), and actually informing or influencing the final decision (e.g. choice of renovation measure, choice of financing, etc.) [6]. Experiences in each of these steps will contribute to the overall positive or negative evaluation of a renovation process, or in short, will determine whether a renovation is considered to be a burden or a success. Via "word of mouth" this evaluation will in turn influence the opinions of other households within the social network. A smooth development of the whole renovation process is therefore an important contributing factor to the success of a national or regional renovation strategy. It is important to address the real concerns and problem framings that households share when considering a renovation. These concerns have to be mapped, and the renovation plans need to show how the concerns will be addressed (timing, division of labour, etc.) [36]. Any impact on the daily routines of the people living in the building needs to be specifically addressed [37]. Qualitative research reported in Breukers et al. [35], Kersten et al. [36] and Wilson et al. [6], points out some 'best practices' w.r.t. renovation projects. Examples of such 'best practices' are:

- The benefits of renovations aiming at improving the energy efficiency of an existing building beyond the impact on energy expenditures should be highlighted. Usually, such renovations also have a positive impact on comfort, aesthetics, noise reduction, maintenance, safety, indoor climate (fewer or smaller temperature fluctuations), etc. In general, the renovation plan should start from a positive framing; concerns should be taken seriously, but can be coupled to realistic actions that show how the concern will be addressed.

- Renovation plans should take into account the differences between households. e.g.:

o Do-it-yourselfers often like to participate in parts of the renovation process;

o Energy-conscious households like to participate in the planning, the selection of technological solutions, discussions on the pros and cons of different technological options, etc.

- Especially when using innovative technologies, people should be made familiar with using these technologies. Testimonials by other households can be used, or the use of the new technology can be demonstrated in a practical setting.

- Enough attention should be paid to a visualisation of the renovation, e.g. by 3D simulation techniques. Households are usually very interested in the aesthetic aspect of the renovation;

- Energy savings after the renovation can be visualised, e.g. by using in-home energy displays that follow up energy consumption in real time. The 'new' energy consumption data can be compared to the 'baseline consumption' - i.e. before the renovation. The comparison can also be made in financial terms.

\section{Reflections on the cost-effectiveness of economic instruments from a societal perspective}

Financial incentives in the form of subsidies or (tax) rebates are frequently used to encourage people to adopt carbon mitigation measures. The incentives may be offered by the government or utilities with a duty to reduce emissions. In the first case they are financed by the taxpayers, while in the second case they are financed by the energy users through their energy bills. Financing the subsidies via higher distortionary ${ }^{8}$ taxation will lead to additional costs for society. The way in which the financial incentives are financed also has an impact on the distribution of the costs and benefits.

The evidence presented above points to a positive impact of financial and fiscal measures. However, most of the reviewed studies do not give conclusive evidence on the energy efficiency improvements or $\mathrm{CO}_{2}$ emission reductions induced specifically by the incentives and therefore on their effectiveness. This is because of the presence of free

\footnotetext{
${ }^{8}$ Distortionary taxes are associated with an intangible efficiency cost, or distortionary cost, in addition to the direct burden of a tax (the amount of tax paid).
} 
riding $^{9}$ : some people would have undertaken the energy efficiency changes anyway, even without the incentives. Therefore, a key issue with such programs is the need to distinguish between additional and non-additional participants. Moreover, the empirical results do not yet shed light on the cost-effectiveness of the measures: the cost per TJ energy saved or per ton of $\mathrm{CO}_{2}$ avoided and how this compares to other policy options. This parameter is also affected by free riding which may substantially increase the costs.

Evidence on the free riding rate and cost-effectiveness associated with subsidy programs is found in many studies, a selection of which are discussed here.

- Grösche \& Vance [38] derive the marginal willingness of German households to pay for energy efficiency renovations based on a data set that combines a nationwide household survey with regional data on wages and construction costs. Almost half of the households have a willingness to pay for energy conservation that exceeds the observed investment costs, which indicates a large potential for free riding. When taking into account a hidden cost such as the inconvenience experienced during the renovation process, the share of potential free-riders falls but is still non-negligible.

- Houde \& Aldy [39] analyse the incremental impact of energy efficiency subsidies on energy outcomes, when they are combined with regulatory measures and information campaigns. For the US State Energy Efficient Appliance Rebate Program implemented through the 2009 American Recovery and Reinvestment Act they find that the ratio of "switchers" (marginal rebate claimants) to "free-riders" (inframarginal rebate claimants) was $1: 10,1: 12$, and $3: 8$, for refrigerators, clothes washers, and dishwashers, respectively. Moreover, depending on the type of appliance, the number of non-takers (i.e. people buying appliances not conforming to the support scheme or people buying conforming appliances but not asking for the subsidy) was $10-30 \%$ of the market. They also find that the rebate programme has led to a small income effect inducing persons to buy larger appliances. In addition, energy efficiency and the attributes used to set the regulation (such as appliance size or style) were inversely correlated, making the rebates implicit subsidies for these attributes other than energy efficiency. The resulting cost per $\mathrm{kWh}$ saved was between $\$ 0.25$ and $\$ 1.50$, depending on assumptions and appliance category. The lower value is four times higher than the average cost-effectiveness of utility-sponsored energy efficiency programs.

- Rivers \& Schiell [40] assess the free-rider rate for Canadian subsidy and tax credits programs between 2007 and 2011 in the case of forced-air natural gas furnaces. They estimate that about half of the subsidies were granted to homeowners who would have chosen an identical furnace during the period covered by the subsidy program even without the subsidy. In the long run (at the time of eventual furnace replacement) around $80 \%$ of homeowners can be termed free-riders. Consequently, the cost per ton of $\mathrm{CO}_{2}$ avoided was between $\$ 70$ and $\$ 110 / \mathrm{tCO}_{2}$, much higher than the cost of other available policy options.

- For a national appliance replacement program in Mexico, about half of the participants are found to be free-riders (Boomhower \& Davis [41]). Taking into account these non-additional participants approximately doubles the program cost per unit of reduced energy consumption. Moreover, while the participation rate increases with the level of the subsidies, most households would have participated even with much lower subsidy levels. This indicates a large potential for cost savings by a better design of the subsidies.

\footnotetext{
${ }^{9}$ Note that financial incentive programs may also lead to free-drivers as opposed to free-riders: the incentive programs may raise the awareness of households who then undertake the improvements but do not apply for the incentives (Alberini \& Bigano [23]).
}

Therefore, while subsidies and rebates are a popular measure, it can be concluded that they are fraught with problems, mainly because of free riding. Together with the income effect and other potential problems related to the design of the subsidies, this leads to a low costeffectiveness. Designing the subsidy systems to minimise free riding is difficult.

Moreover, even if free riding is low, the cost-effectiveness of the programs may still be unattractive, as is indicated by Alberini \& Bigano [23] based on a stated preference survey among Italian homeowners who stated that they were not considering a replacement of their heating equipment any time soon. These were selected in order to minimise issues of adverse selection and free riding. The likelihood of replacing the heating equipment was found to increase when the energy cost savings are larger and last for a longer period, and when rebates are given. Each $\$ 100$ increase in the incentive leads to a 3\% higher likelihood of replacement. While the cost-effectiveness of the rebates was reasonable for high reductions achieved and low subsidy levels, for realistic values of the achieved reductions the subsidy leads to a high cost per ton $\mathrm{CO}_{2}$ avoided, up to more than $\$ 1000 /$ ton of $\mathrm{CO}_{2}$ avoided.

Other aspects of subsidy design are considered by Dubois \& Allacker [42]. Using a stylised economic model, they derive rules for optimal subsidies in a context where people can choose to (i) renovate a house, (ii) reconstruct a house either by demolishing and reconstructing an existing house or by a deep renovation of an existing house, (iii) build a new house on virgin land, besides purchasing a house without making significant changes or renting a house. They show that in order to maximize welfare, subsidies for reconstruction should exceed subsidies for renovation as well as subsidies for building on virgin land. The latter may be negative (i.e. a tax) if the externality associated with building on virgin land is large. They also consider second-best policies if the government is restricted to using one instrument only. If only renovation subsidies can be used, the sign of the optimal subsidy is ambiguous: renovations with minor energy savings should be taxed rather than subsidised, because they induce a lock-in, leading to welfare costs that outweigh the minor energy savings. If the government can only grant reconstruction subsidies, the optimal subsidy is positive. If it can only work through subsidies for building on virgin land, it is optimal to apply a tax rather than a subsidy.

Besides subsidies or tax rebates, which are associated with a number of problems, energy and $\mathrm{CO}_{2}$ taxation play a role to encourage people to save energy and reduce $\mathrm{CO}_{2}$ emissions, since the reviewed studies indicate that people are responsive to savings in energy costs and expected price increases in the future. A correct pricing of energy is also required to mitigate the rebound effects of regulatory measures. In the EU-28 the share of taxes in the price of heating oil and natural gas was on average $28 \%$ and $23 \%$ respectively (in the first quarter of 2014). This can be compared to a tax share of $51 \%$ and $57 \%$ in the price of automotive diesel and gasoline [43]. The relatively low levels of energy taxation for residential use compared to automotive energy implies that there are still many opportunities to be grasped in the sector to improve energy efficiency.

In estimating the impact of energy tax reforms, it should however be taken into account that demand is relatively inelastic, as shown in the panel data studies discussed before. Raising energy taxes raises concerns about undesirable distributional effects. Flues \& Thomas [44] indicate that the share of heating fuel taxes and electricity taxes in household net income is still generally low. For heating oil it lies between $0.48 \%$ and $0.01 \%$ for the EU countries considered in their analysis, depending also on the income class. On average the tax is slightly regressive. For electricity these percentages lie between $1.5 \%$ and $0 \%$, with a somewhat more regressive structure. With higher energy taxes these shares and therefore the salience of energy costs could increase, leading - all else being equal - to a higher price sensitivity. Distributional concerns could be tackled by a well-designed use of the additional tax revenues. 


\section{Conclusions}

From the quantitative studies, it can be inferred that changes in the economic costs and benefits of the choice options for carbon reduction efforts in residential buildings have the expected impact. In some studies however, it is found that people do not take into account all types of costs, possibly due to lack of awareness or because some cost components are small.

When financial incentives (private or public) and subsidies are taken into account explicitly, most of the reviewed quantitative studies find that they have a positive impact on the probability of energy efficiency improvements being undertaken. However, when evaluating the energy efficiency improvements or $\mathrm{CO}_{2}$ reductions induced by the incentives and therefore their effectiveness, the presence of free riding turns out to be a problem: a significant number of people would have undertaken the energy efficiency upgrading measures anyway, even without the incentives. A high level of free riding leads to a low costeffectiveness of the measures. Moreover, even if free riding is low, the cost-effectiveness of the programs may still be unattractive.

Besides the policy instruments of subsidies and tax rebates, which are associated with a number of problems, energy and $\mathrm{CO}_{2}$ taxation should play a larger role in encouraging people to save energy and reduce $\mathrm{CO}_{2}$ emissions, since the reviewed studies indicate that people are responsive to savings in energy costs and expected price increases in the future. A correct pricing of energy is also required to mitigate the rebound effects of regulatory measures. The relatively low levels of energy taxation for residential use compared to automotive energy imply that there are still many opportunities to be grasped in the sector to improve energy efficiency. In estimating the impact of energy tax reforms, it should, however, be taken into account that demand is relatively inelastic. Moreover, distributional concerns should be tackled by a well-designed use of the additional tax revenues.

For information policies the quantitative evidence is still limited. The reviewed panel data studies find no or a negative impact. This finding however does not necessarily imply that information policies are useless, as panel data do not allow for a detailed analysis of different types of informational approaches. The positive effects of successful information campaigns can on average be 'masked' by less well thought-out campaigns in the panel data. More details about the type of informational measures, as well as other quantitative approaches are needed to paint a more accurate picture and draw conclusions about a good design of such policies. Situated accounts already provide many useful insights for aligning the implementation of carbon mitigation measures with daily household routines and practices. In a renovation process, enough attention should be paid to the different stages of getting motivated (e.g. by offering the right type of incentive to the right type of people, e.g. tapping into environmental values and attitudes for environmentally conscious households), shaping decision intentions (e.g. by visualising the renovation, stressing positive impact on aesthetics and comfort, etc.), and actually informing or influencing the final decision (e.g. by tailoring the choice of renovation measure, choice of financing solution, etc. to the specifics of the household situation). Experiences in each of these steps will contribute to the overall positive or negative evaluation of renovation projects. Insights from situated accounts should therefore also be taken into account in the design of a national or regional renovation strategy.

Only the panel data studies allow conclusions to be drawn as to the relative effectiveness of the other policy types. The messages are mixed. While one study finds that financial incentives have the largest impact, another study that looks at the dynamics of the policy effects finds that regulatory policies have an immediate impact, while financial policies only have an impact, which is also smaller, after 7 years. An important drawback of the panel data studies is that only the presence of different policy types is used as an explanatory variable, instead of the exact characterisation of the policies or policy packages. They can therefore only give a rough indication of policy effectiveness. Finally, the concern that regulatory policies could also lead to counter-active side effects is voiced in some studies, but no empirical evidence on this is available yet.

\section{Acknowledgements}

The research reported in this paper was financed by the Ecodistr-ICT project of the FP7 Framework Programme of the European Commission (Call FP7-2013-NMP-ENV-EeB, Grant agreement 608913). This research funding is gratefully acknowledged. However, the opinion stated in this paper reflects the opinion of the authors and not the opinion of the European Commission.

Annex

See Tables 2 and 3. 


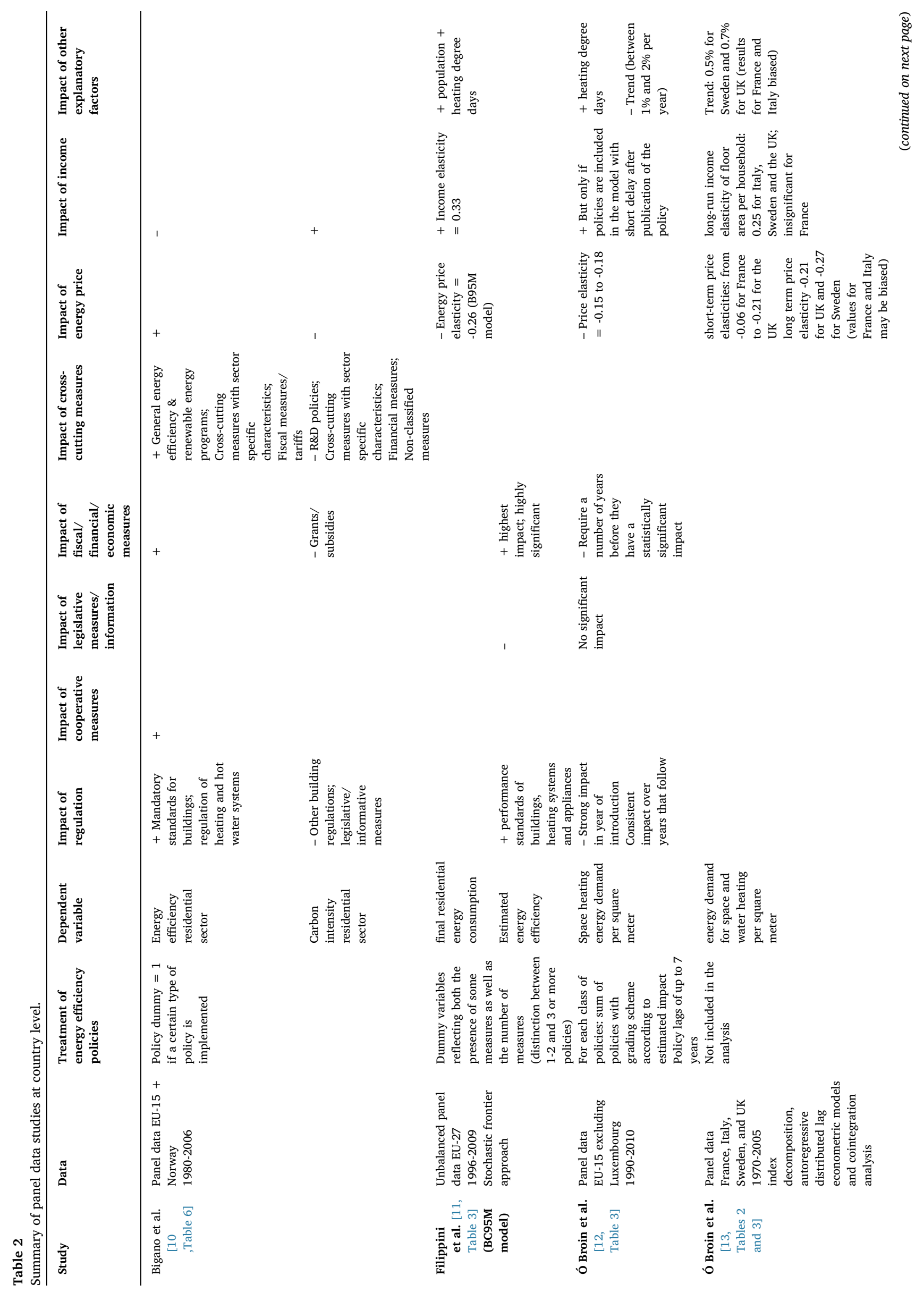



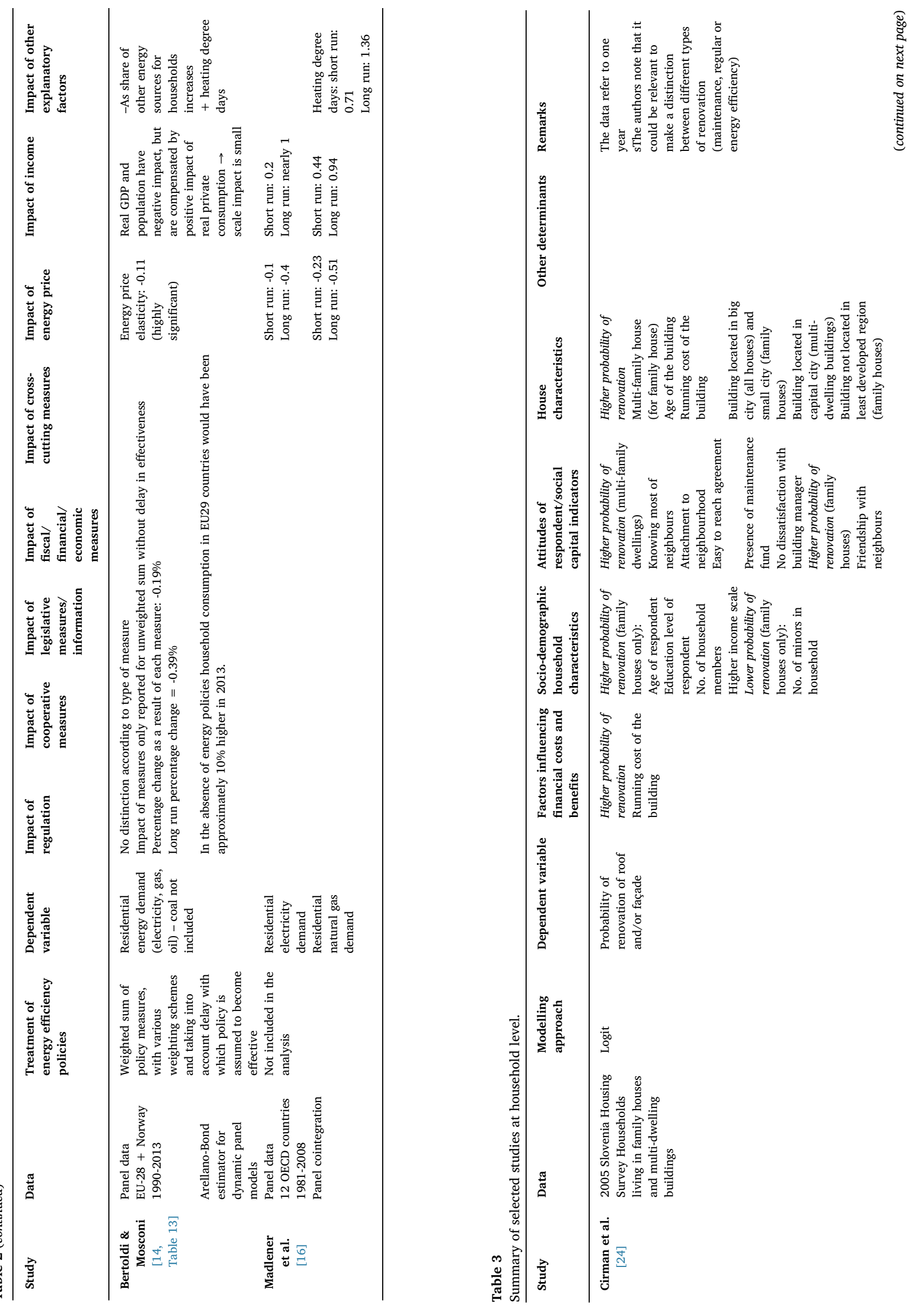


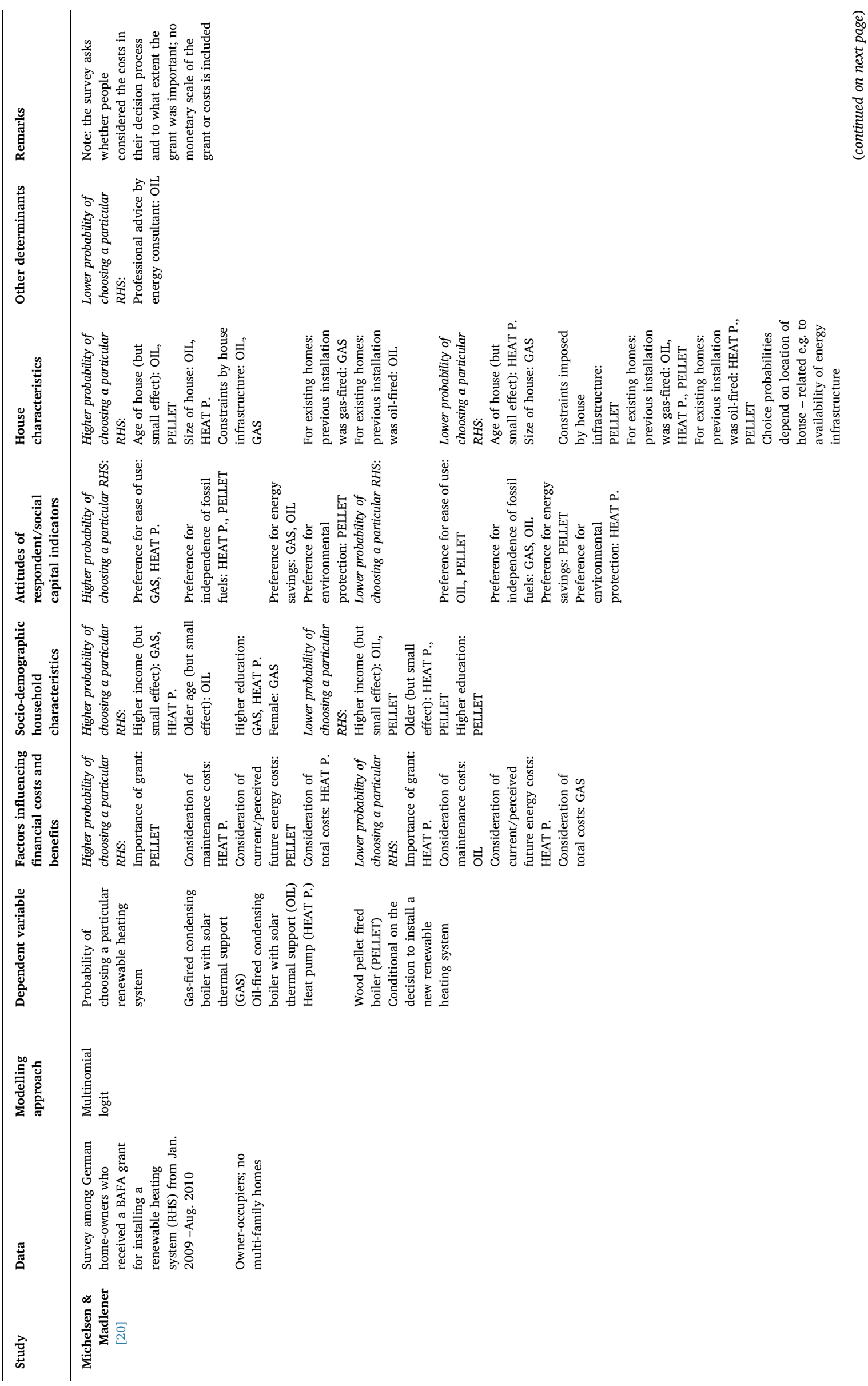




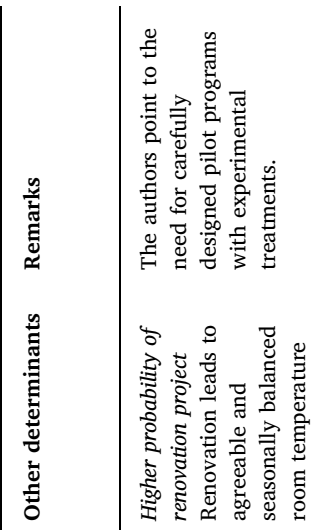
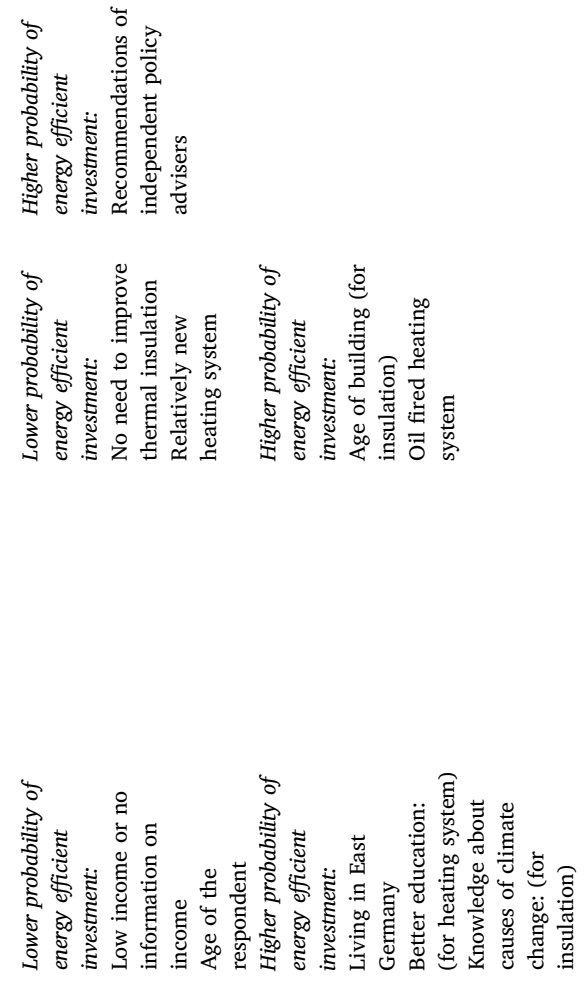

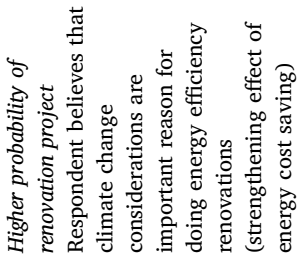

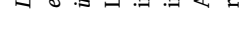

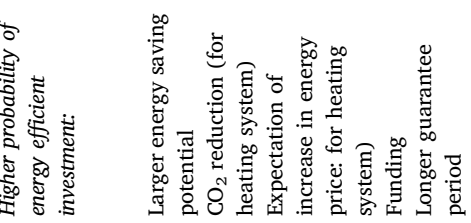

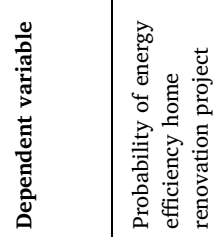

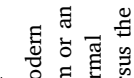

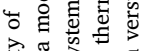

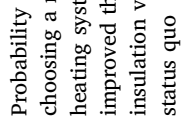

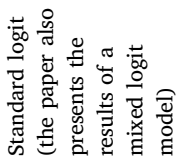

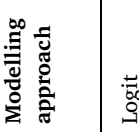

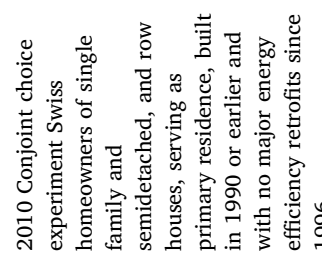

蒫

范

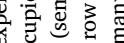

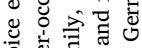

ปิ

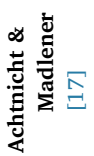




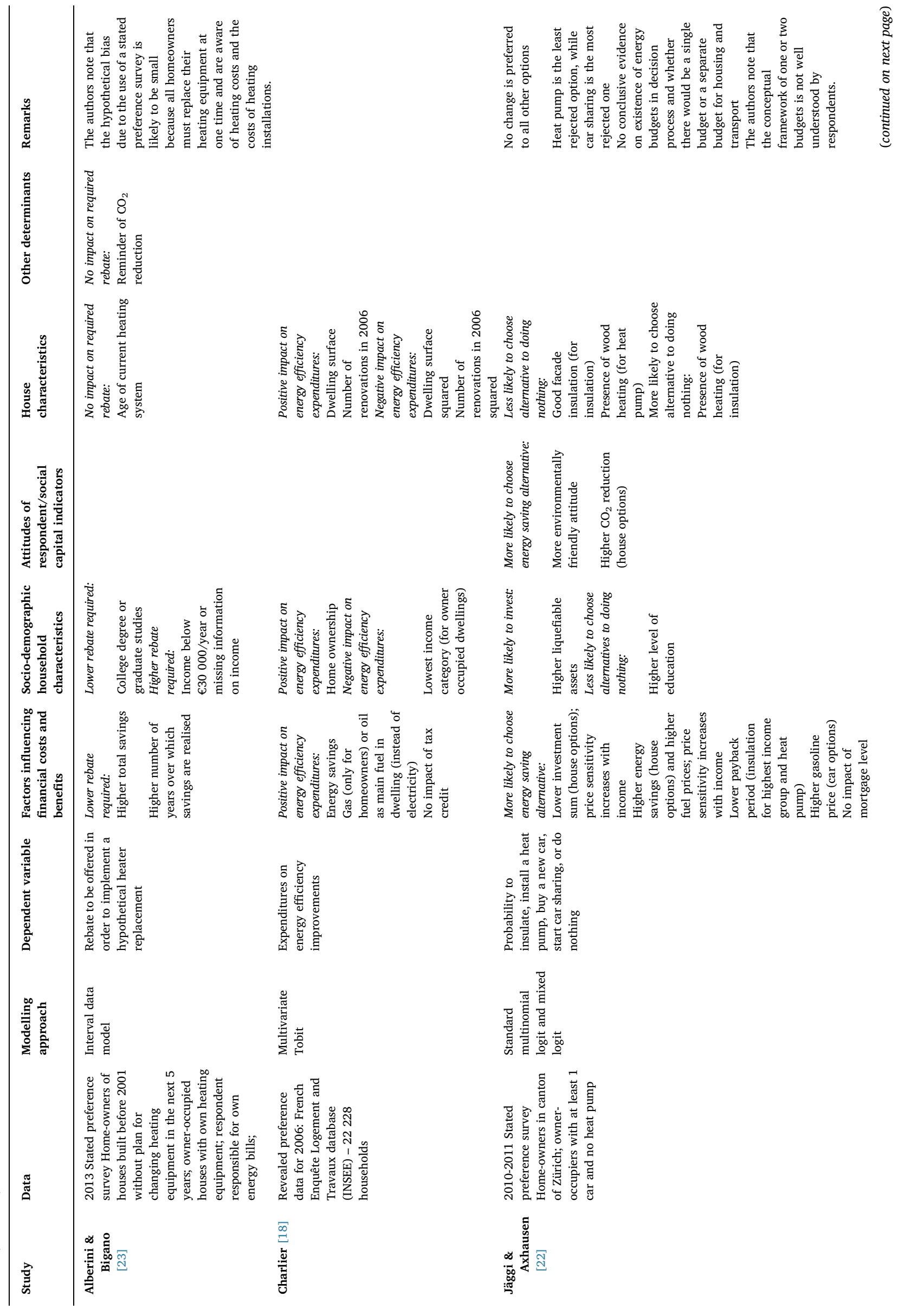




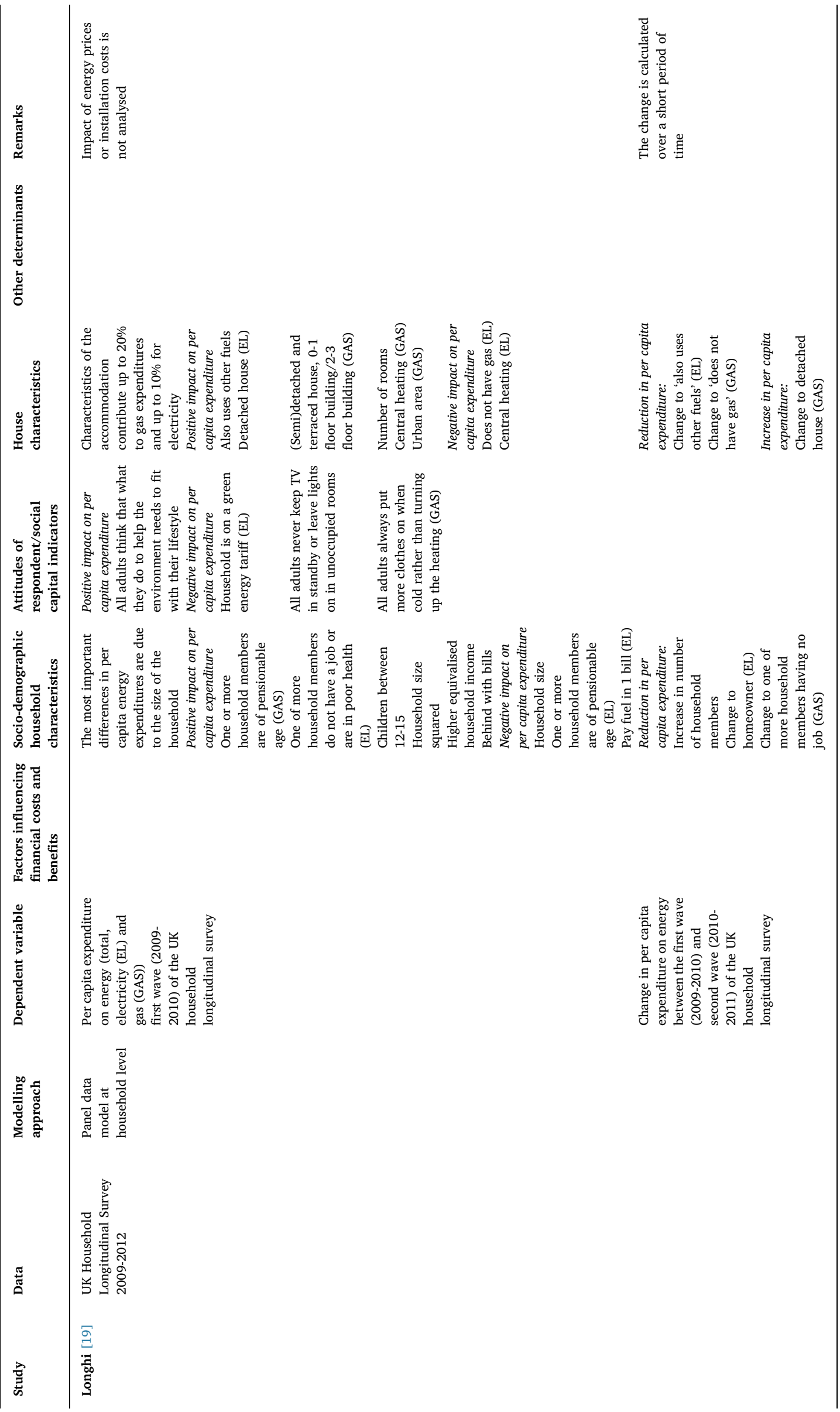




\section{References}

[1] European Commission, Living well, within the limits of our planet: 7th EAP - The new general Union Environment Action Programme to 2020, European Commission; 2013.

[2] European Council. Presidency conclusions of the Brussels European Council of 29/ 30 October 2009, doc 15265/1/09; 2009.

[3] ENTRANZE consortium. Report on specific features of public and social acceptance and perception of nearly zero-energy buildings and renewable heating and cooling in Europe with a specific focus on the target countries, Deliverable 2.6 of the ENTRANZE project.

[4] Eurostat. Distribution of population by tenure status; 2016. Available at $\langle$ http://ec. europa.eu/eurostat/web/products-datasets/-/ilc_lvho02> [Accessed 20 September 2016].

[5] Faiers A, Cook M, Neame C. Towards a contemporary approach for understanding consumer behaviour in the context of domestic energy use. Energy Policy 2007;35:4381-90.

[6] Wilson C, Crane L, Chryssochoidis G. Why do homeowners renovate energy efficiently? Contrasting perspectives and implications for policy. Energy Res Social Sci 2015;7:12-22.

[7] Whitmarsh L, Upham P, Poortinga W, McLachlan C, Darnton A, Devine-Wright P. Public attitudes, understanding, and engagement in relation to low-carbon energy: a selective review of academic and non-academic literatures. London: Research Councils UK; 2011.

[8] Odyssee-Mure. Synthesis: Energy Efficiency Trends and Policies in the EU, An Analysis Based on the ODYSSEE and MURE Databases, September 2015; 2015.

[9] BPIE. Europe's buildings under the microscope, a country-by-country review of the energy performance of buildings. Brussels, Belgium: Buildings Performance Institute Europe; 2011.

[10] Bigano A, Ortiz RA, Markandya A, Menichetti E, Pierfederici R. The linkages between energy efficiency and security of energy supply in Europe, FEEM Working Paper 64.2010; 2010. Available at 〈http://ssrn.com/abstract $=1625756\rangle$ or http:// dx.doi.org/10.2139/ssrn.1625756.

[11] Filippini M, Hunt LC, Zorić J. Impact of energy policy instruments on the estimated level of underlying energy efficiency in the EU residential sector. Energy Policy 2014;69:73-81.

[12] Broin Ó, Nässén E, J, Johnsson F. Energy efficiency policies for space heating in EU countries: a panel data analysis for the period 1990-2010. Appl Energy 2015;150:211-23.

[13] Broin Ó, Nässén E, J, Johnsson F. The influence of price and non-price effects on demand for heating in the EU residential sector. Energy 2015;81:146-58.

[14] Bertoldi P, Mosconi R. The impact of energy efficiency policies on energy consumption in the EU Member States: a new approach based on Energy Policy indicators, JRC Science for Policy Report, European Union; 2015.

[15] Itinera. Kunnen tweeverdieners nog een modale nieuwbouwwoning betalen? (Can double income households still afford a new house?), Itinera Institute; 2011.

[16] Madlener, R., BernsMadlener, R., Bernstein, R. \& Alva González, M.Á., Econometric estimation of energy demand elasticities, E.ON energy research center series, Volume 3, Issue 8; 2011.

[17] Achtnicht M, Madlener R. Factors influencing German house owners' preferences on energy retrofits. Energy Policy 2014;68:254-63.

[18] Charlier D. Energy efficiency investments in the context of split incentives among French households. Energy Policy 2015;87:465-79.

[19] Longhi S. Residential energy expenditures and the relevance of changes in household circumstances. Energy Econ 2015;49:440-50.

[20] Michelsen CC, Madlener R. Homeowners' preferences for adopting innovative residential heating systems: a discrete choice analysis for Germany. Energy Econ 2012;34:1271-83.

[21] Alberini A, Banfi S, Ramseier C. energy efficiency Investments in the home: Swiss homeowners and expectations about future energy Prices. Energy J
2013;34(1):49-96.

[22] Jäggi, B. and K.W. Axhausen (2015), Modelling Long Term Investment Decisions in Housing and Transportation, Chapter 3 in: B. Jäggi, Decision modelling on household level for energy, fleet choice and expenditure, PhD dissertation, ETH Zürich.

[23] Alberini A, Bigano A. How effective are energy-efficiency incentive programs? Evidence from Italian homeowners. Energy Econ 2015;52:S76-85.

[24] Cirman A, Mandic S, Zoric J. What determines building renovation decisions? The case of Slovenia, paper presented at Enhr Conference 2011, Toulouse, France; 2011.

[25] Hassett KA, Metcalf GE. Energy conservation investment. Energy Policy 1993;21(6):710-6.

[26] Gram-Hansen K. Residential heat comfort practices: understanding users. Build Res Inf 2010;38(2):175-86.

[27] Guerra-Santin O, Itard L. Occupants' behaviour: determinants and effects on residential heating consumption. Build Res Inform 2010;38(3):318-38.

[28] Buchanan K, Russo R, Anderson B, B. The question of energy reduction: the problem (s) with feedback. Energy Policy 2015;77:89-96.

[29] Darby S. Smart metering: what potential for householder engagement? Build Res Inform 2010;38(5):442-57.

[30] Ehrhardt-Martinez K. Advanced metering initiatives and residential feedback programs: a meta review for household electricity savings opportunities. Washington, USA: ACEEE; 2010.

[31] Staats H, Harland P, Wilke H. Effecting durable change: a team approach to improve environmental behavior in the household. Environ Behav 2004;36:341-67.

[32] Black R, Davidson P, Retra K. Facilitating energy saving behaviors among university student residents, Institute for Land Water and Society, Report No. 53; 2009.

[33] Ayres I, Raseman S, Shih A. Evidence from two large field experiments that peer comparison feedback can reduce residential energy usage, In: Proceedings of the 5 th annual conference on empirical legal studies paper, social science research network working paper series.

[34] Buchanan K, Russo R, Anderson B. Feeding back about eco- feedback: how do consumers use and respond to energy monitors? Energy Policy 2014;73:138-46.

[35] Breukers S, van Summeren L, Mourik R. Eerst proces, dan prestatie. Naar een optimale afstemming tussen aanbieders, bewoners en de woning in renovaties richting energieneutraliteit (First the process, then the results. Towards an optimal configuration of providers, inhabitants and the dwelling in renovation processes aiming for energy neutrality). Duneworks, The Netherlands; 2014.

[36] Kersten WC, Crul MRM, Geelen DV, Meijer SA, Franken V. Engaging beneficiaries of sustainable renovation - exploration of design-led participatory approaches. J Clean Prod 2015;106:690-9.

[37] Monno V, Khakee A. Tokenism or political activism? Some reflections on participatory planning. Int Plan Stud 2012;17:85-101.

[38] Grösche P, Vance C. Willingness-to-pay for energy conservation and free-ridership on subsidization: evidence from Germany. Energy J 2009;30:141-60.

[39] Houde S, Aldy JE. Belt and Suspenders and More: The Incremental Impact of Energy Efficiency Subsidies in the Presence of Existing Policy Instruments, RFF Working Paper 14-34, Resources for the Future; 2014.

[40] Rivers N, Shiell L. Free riding on energy efficiency subsidies: the case of natural gas furnaces in Canada, Working Paper, University of Ottawa; 2015.

[41] Boomhower J, Davis LW. A credible approach for measuring inframarginal participation in energy efficiency programs. J Public Econ 2014;113:67-79.

[42] Dubois M, Allacker K. Energy savings from housing: ineffective renovation subsidies vs. efficient demolition and reconstruction incentives. Energy Policy 2015;86:697-704.

[43] IEA. Energy prices and taxes, International Energy Agency, Paris; 2015.

[44] Flues, F., Thomas, A., The distributional effects of energy taxes, OECD Taxation Working Papers, No. 23, 2015. OECD Publishing, Paris.

[45] Bateman IJ, Carson RT, Day B, Hanemann M, Hanley N, Hett T, Jones-Lee M, Loomes G, Mourato S, Özdemiroglu E, Pearce D, Sugden R, Swanson J. Economic valuation with stated preference techniques. A manual. Northampton, MA: Edward Elgar; 2002. 